\title{
An integrated fuzzy AHP and TOPSIS model for evaluating the performance of raw material suppliers: A case study in lasem batik writing centre
}

\author{
Diana Puspita Sari ${ }^{1, *}$,Wismar Rizki Wijayanti ${ }^{1}$, Adhie Prayogo ${ }^{1}$, M. Mujiya Ulkhaq $^{1}$, and \\ Dyah Ika Rinawati ${ }^{1}$ \\ ${ }^{1}$ Department of Industrial Engineering, Diponegoro University, 50275 Semarang, Indonesia
}

\begin{abstract}
Batik is labelled as an identity of Indonesia as in 2009 UNESCO recognized batik as a cultural heritage of no object. The export value of batik in 2015 reached USD 156 million. This study aims to evaluate the performance of raw material suppliers using five criteria, i.e., price, quality, delivery, flexibility, and service. The combination of the fuzzy analytic hierarchy process (FAHP) and technique for others reference by similarity to ideal solution (TOPSIS) are used here to achieve the research objective. FAHP was used to determine the weight of each criterion; while TOPSIS was employed to identify the ranking of all alternatives to be considered. A case study was conducted at Lasem batik writing centre. FAHP results show that quality becomes the most important criterion with the weight of 0.266 . The best suppliers of raw materials are LI, PA, and SL for fabrics, dyes, and wax respectively. Findings of this study may offer batik craftsmen in determining what are the best suppliers to be considered based on their performance.
\end{abstract}

\section{Introduction}

The industrial sector plays an important role in national improvement which is useful as an accelerator of development and employment. Thus, the Indonesian Ministry of Industry marks the industry's growth reached $5.67 \%$ in 2018 [1]. The industry which is currently being highlighted by the government is the creative industry. Furthermore, the Blueprint for National Creative Economy mentions that the creative industry derives from the authorization of individual creativity, skills, and talents [2]; it could generate prosperity and employment through the utilization of creative power and creativity of the individual [3]. One type of creative industry is fashion. Based on gross domestic product, this is in the second place with exports of 56\% [4]. The fashion recognized by UNESCO in 2009 as the masterpieces of the oral and the intangible heritage of humanity is batik [5]. Batik is a form of textile that has a variety of ornamental surface with wax-resist dyeing technique in which staining the fabric using wax [6]. There are three types of batik such as stamping batik, printing batik, and writing batik. Stamping batik is made by painting wax on fabric with canting made of copper [7]. Batik imitations that lack the authenticity in terms of post-

\footnotetext{
Corresponding author: dpsari.01@gmail.com
} 
modern aesthetic are called printing batik which is produced by machine [8]. Meanwhile, writing batik is made manually by human hand. Hence, it requires special skills such as technique, thoroughness, and patience [9]. In the first half of 2017, the export value and batik products reached IDR 528 billion with the major destinations are Japan, the United States, and Europe [10].

Nevertheless, the export value is not matched by batik industry condition. Batik industry has various problems especially in the supply of raw materials. The problems occur such as dyes and wax sold by suppliers have low quality, the supplier is not responsible for damage to raw materials received by craftsmen such as defects in fabric, and unstable prices. It disserves the craftsmen in producing a high-quality batik. Conse-quently, it is essential to apply an effective tool to measure the supplier performance of batik raw materials. It should develop decision-making in approval. Therefore, multi-criteria decision-making theory (MCDM) can be applied in evaluating supplier perfor-mance from several alternatives. MCDM theory is a discipline that aims to support decision makers confronted with formulating diverse and conflicting evaluations [11]. Analytical Hierarchy Process (AHP) is a popular method and able to produce solutions in accordance with perceptions and expectations [12]. The main advantage of this method is the buyer can obtain a reliable overview of supplier performance by using hierarchy criteria and evaluating suppliers [13]. Conversely, it also has the disadvantage of not considering the risks and uncertainties regarding supplier performance [14]. Fuzzy is a method that captures and uses the concept of uncertainty in an effective calculation [15]. It has been combined with AHP to present fuzzy AHP (FAHP). It is a refinement of the AHP [16] that can facilitate the real-life situations to make effective decisions [17]; see [18-19] for the FAHP applications.

This study tried to combine the FAHP with technique for order preference by similarity to ideal solution (TOPSIS) [20]. It has high flexibility and accommodates advance extensions to make better selections in various situations [21]. The combination of these two methods can be seen in [22]. To apply these methods, a case study was conducted to evaluate raw material supplier performance in Lasem writing batik centre with the main raw materials consist of fabrics, dyes, and wax. Lasem writing batik centre was chosen owing to the increase of craftsmen from 22 in 2004 to 77 craftsmen in 2016 [23]. Besides, the export of Lasem batik also increased by $20 \%$ per year [24]. Oppositely, this condition is not equivalent with the supplier performance. Thus, the objectives of this research are twofold. The first is to indicate how to define the importance of assessment criteria for supplier performance using the FAHP method. The second is to ascertain the ranking of each alternative using TOPSIS technique. The findings in this research may help batik craftsmen in determining suppliers for their raw materials.

\section{Research design}

In this study, the main raw materials considered in evaluating the performance of suppliers in Lasem batik centre consist of fabric, dye, and wax. The fabric alternative consists of three suppliers called LI, PA, and JE. The dye alternatives consist of five suppliers; they are called WI, SA, PA, JE, and NA. Meanwhile, wax alternatives consist of five suppliers called SA, PA, PU, LU, and SL. This evaluation is determined in five criteria, i.e., price, quality, delivery, flexibility, and service. They were selected by literature review [25] [26] and in-depth interviews with several experts. The first criterion is price, which is the quantity of the goods given or acquired in exchange for other goods [27]. It consists of three subcriteria, including low price, free distribution cost and discounts for bulk orders. The second is quality; that is described by a characteristic of product or service to satisfycustomers [28]. This criterion includes achieving the minimum standard, durability, andlow re- 


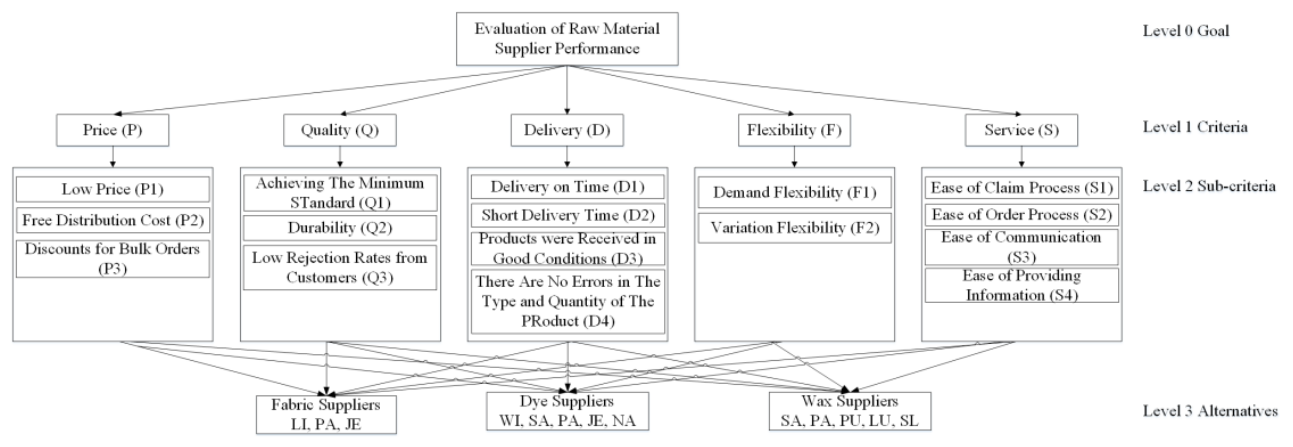

Fig. 1. The hierarchy model of the decision making.

jection rates from customers. The third criterion is delivery. Delivery is a process of moving goods from one location to the specific location [29]. It involves four sub-criteria, i.e., delivery on time, short delivery time, products were received in good conditions and there are no errors in the type and quantity of the product. An ability of a system to adapt to the external change is the fourth criteria namely flexibility [29]. It consists of two sub-criteria, demand flexibility and variation flexibility. The fifth criterion was service. It is defined as activities provided by the seller that can improve the product and value for buyers, thus increasing customer satisfaction [30]. It comprises four sub-criteria, such as ease of claim process, ease of order process, ease of communication, and ease of providing information. Besides selection the most preferred criterion, another goal of the study is to find out the supplier performance among the alter-natives previously mentioned. In order to apply the FAHP and TOPSIS to evaluate the performance of supplier, the above criteria are arranged to different levels of hierarchy. The hierarchy of the decision model is depicted in Figure 1, where the objective is to evaluate raw materials supplier performance. Data used were collected from three experts consist of Lasem batik writing clusters chairman (2017present), Lasem batik writing clusters chairman (2012-2016) and Lasem batik chairman of BNI partners (2015-present). The evaluation phase of supplier performance assessment consists of two main steps. Firstly, assessing the weights of each criterion using FAHP. Experts were asked to compare between criteria by pairwise comparison. This is to estimate their importance in relation to each other's criteria. A nine-point questionnaire is used to demonstrate expert judgments among criteria as equally, moderately and extremely important. Second, the alternative rating is obtained by TOPSIS method; based on the weight of each of the previously identified criteria.

FAHP were conducted to evaluate the performance of raw material suppliers for Lasem writing batik center. The FAHP technique is accepted as an advanced method developed from traditional AHP. In complex systems, human thinking, including experience and judgment is represented by linguistics and vague patterns that can be developed as quantitative data. Then, the data was refined by the method of evaluation of fuzzy set theory. In another case, conventional AHP still can ot reflect human thinking; in order to avoid this risk on performance evaluation, FAHP is done [31]. FAHP alters the linguistic assessment in triangular fuzzy numbers (TFNs). A TFN is denoted as $\mathrm{M}=(l, m, u)$ if its membership function $\mu_{\mathrm{M}}(x): R \rightarrow[0,1]$. Where $l \leq m \leq u ; l, u$, and $m$ are lower, upper, and mid-value of the support of $M$ respectively. The support of $M$ is the set of elements $\{x \in R \mid l<x<u\}$. Let TFNs $\mathrm{M}_{1}, \mathrm{M}_{3}, \mathrm{M}_{5}, \mathrm{M}_{7}$, and $\mathrm{M}_{9}$ deputize the assessment from equally to extremely important; and $\mathrm{M}_{2}, \mathrm{M}_{4}, \mathrm{M}_{6}$, and $\mathrm{M}_{8}$ are as the middle values. Given $X$ $=\left\{x_{1}, x_{2}, \ldots, x_{n}\right\}$ be an object set and $U=\left\{u_{1}, u_{2}, \ldots, u_{n}\right\}$ be an objective set. Each object is taken to perform level analysis for each goal. 
TOPSIS is one of the methods used for solving multiple criteria decisions or problems that developed by [20], with further developments by [32]. It evaluates the alternatives with measuring their distance to the positive ideal solutions (PIS) and to the negative ideal solution (NIS). The TOPSIS algorithm stage can be classified into several steps. Firstly, change of the decision-making matrix into a normalized decision matrix. Let $Z$ is a normalized decision matrix representing the relative performance of the generated design alternatives. Where $y_{i j}$ is the performance score of alternative $j$ against criterion $i(i=1,2$, $\ldots, n$ and $j=1,2, \ldots, k)$. Second, calculate the weighted decision matrix. Let $X_{i j}$ be the weighted normalized decision matrix. Then, calculate the values of distance from PIS and NIS. Let the $S_{j}^{+}$denotes the distance of each alternative from PIS and $S_{j}^{-}$denotes the distance of each alternative from NIS. The next step is to calculate the relative closeness coefficient of each alternative to the ideal solution. Lastly, the available alternatives are ranked according to the closeness coefficient on the downside order. The best alternative is closest to the PIS and farthest from the NIS.

\section{Case study: Results and discussion}

The objective of this research is to evaluate raw material supplier performance in Lasem writing batik center with the main raw materials consist of fabrics, dyes, and wax. It is divided into two consecutive steps; first is to determine the preferred criterion among the five criteria and sixteen sub-criteria using FAHP and the second is to identify alternative rankings using the TOPSIS technique. Three respondents who act as decision makers were asked to fill in pairwise comparisons to express their preferences between alternatives, criteria, and sub-criteria in the nine-point questionnaire. Note that the consistency test successfully ensured that the pairwise comparison matrix reasonable and acceptable where the consistency ratio is below the threshold of 0.1 ; it can be used for further analysis. The FAHP is used to determine the weights for each criterion. After accomplishing several calculations using FAHP, the weight for each criterion is 0.211 for price, 0.266 for quality, 0.222 for delivery, 0.208 for flexibility, and 0.092 for service.

According to the result, quality becomes the most important thing; the quality of raw materials will affect the results of batik produced. As can be seen in Table 1, the most important sub-criteria in quality is durability of $35.3 \%$ that means raw materials can be used for long periods of time; followed by a low rejection/refund rate of $32.8 \%$ and meet minimum standards with $31.9 \%$. Delivery is regarded as the second most important criterion since a raw material when delivered is not timely and not in good condition; it will inhibit the production process. Products are received in good condition is believed to be most important with the weight of $28.1 \%$. The subsequent is delivery on time and there are no errors in the type and quantity of the product with $26 \%$; while the least important subcriterion is short delivery time with $19.9 \%$. The third most important criterion is price. It becomes an important criterion because batik craftsmen will definitely choose the supplier with low price but with good quality. If the price is pricey then the benefits of batik craftsmen are low and vice versa. The weights for its sub-criteria are as follows. Low price as the most important weight of $52.7 \%$; followed by free distribution cost of $44.7 \%$, and discounts for bulk orders of $2.6 \%$. Moreover, flexibility becomes the fourth most important criterion. This criterion is considered important since batik craftsmen need suppliers who are able to meet the amount and variety of raw materials needed in large quantities. It only has two sub-criteria where demand flexibility of $93.7 \%$ surpasses variation flexibility with $6.3 \%$. The last important criterion is service. Craftsmen are not too concerned about the services provided by the supplier and more focused on the other criterion. It has four subcriteria; ease of information delivery process becomes the most important sub-criteria with 
the weight of $37.6 \%$; whereas ease of communication of $36.1 \%$, ease of order process of $21.8 \%$, the last is the ease of claim process of $4.5 \%$.

After determining the criteria and sub-criteria weights, the TOPSIS technique is then applied to select the best alternative for each raw material. The first alternative in raw materials of fabric i.e., LI surpasses PA and JE, for ten sub-criteria, there are discount for bulk orders, meet the minimum standards, durability, low rejection/refund rate, there are no errors in the type and quantity of the product, demand flexibility, ease of claims process, ease of order process, ease of communication, and ease of providing information. The experts view LI were having a high performance in order to supply fabric to satisfy the craftsmen's needs. They also believe that LI can supply fabric with better quality, flexibility, and service than other suppliers. For batik craftsmen, the quality of raw materials is the most vital thing to be fulfilled. It is because the raw materials used will affect the product of batik produced. On the other hand, PA is superior in two sub-criteria i.e., free distribution cost and short delivery time. Decision makers also believe that PA has the lower price and faster delivery than others. Lastly, JE exceeds others only in one subcriteria namely flexibility variation. Experts also said that JE is better at meeting the variety of needs of batik craftsmen. Finally, TOPSIS technique ranks the best alternative according to the relative proximity to the ideal solution. The results showed on the fabric alternative, LI came out as the top, followed by PA and then JE; in the dye alternatives show that PA as the top, followed by NA, JE, WI, and last SA; while the wax alternatives indicate that the top position is LU, followed by SL, PU, PA, and then SA.

\section{Conclusion}

The aims of this research is to evaluate raw material supplier performance in Lasem writing batik center with the main raw materials consist of fabrics, dyes, and wax. Data obtained from in-depth interviews with three experts. The results of this study indicate that the criteria with the highest level of importance is quality with the weight of 0.266 (see Section 3 for the detail). The calculation result of FAHP and TOPSIS shows that the best performance of raw material supplier in fabric is LI with a weight of 0,42 , dye is PA of 0.88 , and wax is SL of 0.25 . Where every alternative has its own advantages. Then, Lasem batik writing center must adjust to the needs of raw materials. The reason is other alternatives also have their respective advantages in the criteria and not necessarily worse than the best alternative.

This research is supported by the Faculty of Engineering of Diponegoro University through "Strategic Research" grand.

\section{References}

1. S. Gareta, (2018)

2. Departemen Perdagangan Republik Indonesia, Pengembangan Ekonomi Kreatif Indonesia 2025: Rencana Pengembangan Ekonomi Kreatif Indonesia 2009-2015 (Departemen Perdagangan Republik Indonesia, Jakarta, 2008)

3. Badan Ekonomi Kreatif Republik Indonesia, (2017)

4. B. Galih (2009)

5. S.D. Lestari, Mengenal Aneka Batik (Balai Pustaka, Jakarta, 2012)

6. Ismadi, Evolusi batik dahulu dan sekarang, in Proceeding of Seminar Nasional Batik Empowering Batik dalam Membangun Karakter Budaya Bangsa, 316-331 (2011). 
7. A. Oscario, Humaniora, 5 (2014)

8. Komunitas Pelestari Batik Tulis (2014)

9. P. A. Julianto, (2017).

10. M.M. Ulkhaq, W.R. Wijayanti, M.S. Zain, E. Baskara and W. Leonita, Proceeding of 2nd International Conference on High Performance Compilation, Computing and Communications, (2018)

11. N. Bhushan and K. Rai, Strategic Decision Making Applying the Anlytic Hierarchy Process (Springer, Berlin, 2004)

12. S. Omkarprasad and S. Kumar, EJOR, 169 (2006)

13. R.M. Yusuff, K.P. Yee and M.S.J. Hashmi, 17 (2001)

14. B.A. Sproule, C.A. Naranjo and I.B. Türksen, Trends in Pharmacological Sciences, 23 (2002)

15. D. Chang, Eur. J., Open Res, 95 (1996)

16. F.T.S. Chan and N. Kumar, Omega, 35 (2007)

17. M.M. Ulkhaq, R.L. Nartadhi, P.Y. Akshinta, Ind. Eng. Manag. Syst., 15 (2016)

18. M.M. Ulkhaq, P.Y. Akshinta, R.L. Nartadhi, Pramono, S.N.W., Matec Web of Conferences $\mathbf{6 8}$ (2016)

19. C. Hwang and K. Yoon, Methods and Application (Springer, New York 1981)

20. H.S. Shih, H.J. Shyur and E. Lee, Mathematic Computation Model, 45 (2007)

21. R.P. Kusumawardani and M. Agintiara, Procedia Computer Science, 72 (2015)

22. N.N. Maulany and N.N. Masruroh, Patrawidya, 18 (2017)

23. M. Tahwin, D.A.L. Dewi and A.A. Mahmudi, The 2nd University Research Coloquium, 33-42 (2015)

24. A. Susanty, D. Puspitasari, S. Hartini and G. Sugi, ISAHP Article (2014)

25. R. Jain, A. Singh and P. Mishra, MIT International Journal of Mechanical Engineering, 34-42 (2013)

26. J.R. Commons, Research in the History of Economic Thought and Methodology, 18 (2000)

27. A. Akbar (2012)

28. V.Y.M.K. Sharma, Benchmarking: An International Journal (2015)

29. B. Donaldson, European Journal of Purchasing \& Supply Management, 1 (1994)

30. L.A. Zadeh, 8 (1965)

31. K. Yoon, Social, 38 (1987) 